\title{
The 3D8 single chain variable fragment protein suppresses Newcastle disease virus transmission in transgenic chickens
}

\author{
Sung June Byun ${ }^{1}$, Hoonsung Choi ${ }^{1}$, Shanmugam Sureshkumar ${ }^{1}$, Seong-Su Yuk², Jung-Hoon Kwon², Jin-Yong Noh², \\ Sun Keun Jung ${ }^{1}$, Jeom Sun Kim¹, Keon Bong Oh¹, Hyeon Yang ${ }^{1}$, Gunsup Lee ${ }^{1}$, Hwi-Cheul Lee ${ }^{1}$, \\ Jae-Seok Woo ${ }^{1}$ and Chang-Seon Song ${ }^{2^{*}}$
}

\begin{abstract}
Background: The 3D8 single chain variable fragment (scFv) is a mini-antibody sequence that exhibits independent nuclease activity against all types of nucleic acids. In this research, crossing a 3D8 scFv G1 transgenic rooster with wild-type hens produced 3D8 scFv $G_{2}$ transgenic chickens to evaluate suppression of viral transmission.

Result: The transgenic chickens were identified using genomic PCR and immunohistochemistry. To evaluate Newcastle disease virus (NDV) protection conferred by 3D8 scFv expression, transgenic, non-transgenic, and specific pathogen-free (SPF) chickens were challenged with virulent NDV by direct injection or aerosol exposure. The three groups of chickens showed no significant differences $(p<0.05)$ in mean death time after being directly challenged with NDV; however, in contrast to chickens in the non-transgenic and SPF groups, chickens in the transgenic group survived after aerosol exposure. Although the transgenic chickens did not survive after direct challenge, we found that the chickens expressing the 3D8 scFv survived aerosol exposure to NDV.
\end{abstract}

Conclusions: Our finding suggest that the 3D8 scFv could be a useful tool to prevent chickens from spreading NDV and control virus transmission.

Keywords: Newcastle disease virus (NDV), 3D8 ScFv, chicken, transgenic

\section{Background}

Newcastle disease (ND) is an extremely important and economically devastating viral disease in poultry production in many countreis [1]. ND is characterized by high mortality and by nervous, respiratory, enteric, and reproductive infections [2]. The viruses that cause ND are classified in the family Paramyxoviridae under the genus Avulavirus and the species Newcastle disease virus (NDV) or avian paramyxovirus type 1 (APMV-1) [3]. $\mathrm{NDV}$ has a $15 \mathrm{~kb}$ genome consisting of six genes that

\footnotetext{
* Correspondence: songcs@konkuk.ac.kr

${ }^{2}$ Avian Disease Laboratory, College of Veterinary Medicine, Konkuk University, 1 Hwayang-dong, Gwangjin-gu, 05029 Seoul, Republic of Korea

Full list of author information is available at the end of the article
}

encode a negative-sense, single-stranded, enveloped RNA virus. This virus has six structural proteins, including nucleoprotein $(\mathrm{NP})$, phosphoprotein $(\mathrm{P})$, matrix $(\mathrm{M})$, fusion (F), hemagglutinin-neuraminidase $(\mathrm{HN})$, and RNA-dependent RNA polymerase (L) [4], and additional nonstructural proteins $\mathrm{V}$ and $\mathrm{W}$ are encoded through RNA editing of the $P$ gene [5]. In most countries, vaccination plays a vital role in controlling NDV $[6,7]$. Although general immunizations provide excellent protection against clinical disease and mortality, they do not provide adequate protection against the virus and may not prevent ND outbreaks $[8,9]$. Thus, detecting novel antiviral therapeutics for NDV and developing

C C The Author(s). 2020 Open Access This article is licensed under a Creative Commons Attribution 4.0 International License, which permits use, sharing, adaptation, distribution and reproduction in any medium or format, as long as you give appropriate credit to the original author(s) and the source, provide a link to the Creative Commons licence, and indicate if changes were made. The images or other third party material in this article are included in the article's Creative Commons licence, unless indicated otherwise in a credit line to the material. If material is not included in the article's Creative Commons licence and your intended use is not permitted by statutory regulation or exceeds the permitted use, you will need to obtain permission directly from the copyright holder. To view a copy of this licence, visit http://creativecommons.org/licenses/by/4.0/ The Creative Commons Public Domain Dedication waiver (http://creativecommons.org/publicdomain/zero/1.0/) applies to the data made available in this article, unless otherwise stated in a credit line to the data. 
varieties that are resistant to viruses is expected to reduce the damage caused by disease.

The 3D8 single chain variable fragment (3D8 scFv) has shown non-specific DNA and RNA nuclease activity [10]. The $3 \mathrm{D} 8 \mathrm{scFv}$ is generated by using the variable heavy $(\mathrm{VH})$ and variable light $(\mathrm{VL})$ domains of an antiDNA monoclonal antibody isolated from MRL-lpr/lpr mouse spleen cells. The ability of 3D8 scFv to hydrolyze nucleic acids and penetrate cells via a caveolae-lipid raft pathway has prompted its use in multiple antiviral applications [11]. For example, 3D8 scFv treatment of porcine kidney cells confers resistance to classical swine fever virus (CSFV) infection [12]. In addition, antiviral effects of the 3D8 scFv against DNA viruses in a human cell line (HeLa cells) and in mice have been demonstrated by measuring DNase activity and RNase activity [13]. Earlier data from oropharyngeal and cloacal swabs have shown that 3D8 scFv transgenic chickens in a contact delivery group exhibited viral clearance after inoculation with an avian influenza virus [14]. Studies have confirmed that the 3D8 scFv gene can be used as a potentially effective antiviral agent. The objective of this study was to investigate the antiviral effect of the 3D8 scFv against NDV. In this study, we produced, confirmed 3D8 $\mathrm{scFv}$ expressing transgenic chickens. The antiviral effect of the $3 \mathrm{D} 8 \mathrm{scFv}$ was evaluated via direct challenge and aerosol exposure to the virulent Kr005 strain of NDV.

\section{Results}

Production of transgenic chickens expressing the 3D8 scFv In a previous study, the CBA (chicken $\beta$-actin promoter)-3D8 scFv-HA-IRES-puro lentiviral vector was constructed and used to transfect chickens to establish $G_{0}$ transgenic chickens [15]. In the current research, $G_{2}$ transgenic chickens were generated by breeding a $G_{1}$ transgenic rooster and wild-type hens for experiments on antiviral treatments against NDV. To assess 3D8 scFv expression in $G_{2}$ transgenic chickens, genomic PCR was used (Fig. 1, supplementary Fig. 1). PCR results showed that the 3D8 scFv was present in seven of the fourteen
$\mathrm{G}_{2}$ transgenic chickens. The ratio of transgenic to wildtype progeny was $50 \%$ in $\mathrm{G}_{2}$ transgenic chickens, similar to the ordinary mendelian ratio. In addition, 3D $8 \mathrm{scFv}$ expression in transgenic and wild-type chicken tracheal tissues was identified by immunohistochemical staining. Tracheal tissue of 3D8 scFv transgenic chickens showed $\mathrm{scFv}$ expression after DAB staining (Fig. 2b). Immunohistochemical staining revealed that the $3 \mathrm{D} 8 \mathrm{scFv}$ protein was highly expressed in lymphocytes on the surface of the tracheal lamina propria in transgenic chickens. In wild-type chickens, however, the 3D8 scFv was not observed (Fig. 2a).

\section{The 3D8 scFv showed antiviral activity against NDV infection in transgenic chickens}

We verified the antiviral impact of the 3D8 scFv against NDV infection in transgenic chickens. There were three groups of chickens: transgenic, non-transgenic, and SPF chickens. Six chickens from each group were directly infected with NDV via intramuscular injection of the virus. Cage of ten chickens per each group were connected with the cage of directly challenged chickens through a hose with airflow to determine viral transmission by exposure of the virus to chickens via aerosol. During the experimental periods, chickens were observed daily for clinical signs and mortality. NDV directly challenged chickens showed clinical signs including lethargy and depression and there was no significant difference in mean death time among groups $(p<0.05)$ (Table 1; Fig. 3). However, among the aerosol exposure groups, only the 3D8 scFv transgenic chickens survived after aerosol exposure to NDV, whereas the non-transgenic and SPF chickens showed clinical signs and died after aerosol exposure (Table 2; Fig. 4).

\section{Discussion}

ND is extremely contagious and readily spreads from bird to bird. The infection is generally spread through

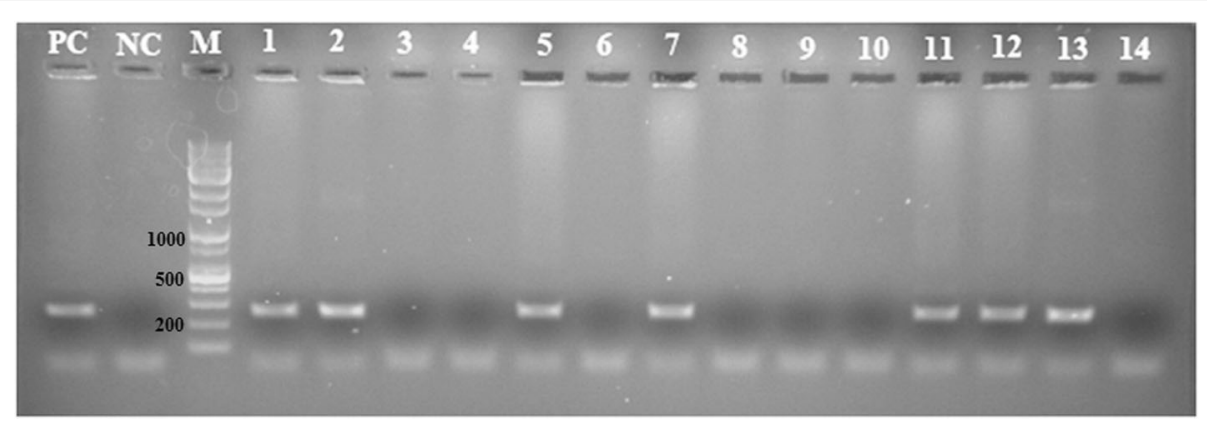

Fig. 1 Confirmation of 3D8 scFv gene expression in $G_{2}$ tg. Genomic PCR analysis of the $G_{2} 3 D 8$ scFv tg progeny chickens. The PCR product size is 270 bp. M: 1 kb Plus DNA ladder (SolGent), NC: negative control, PC: positive control 


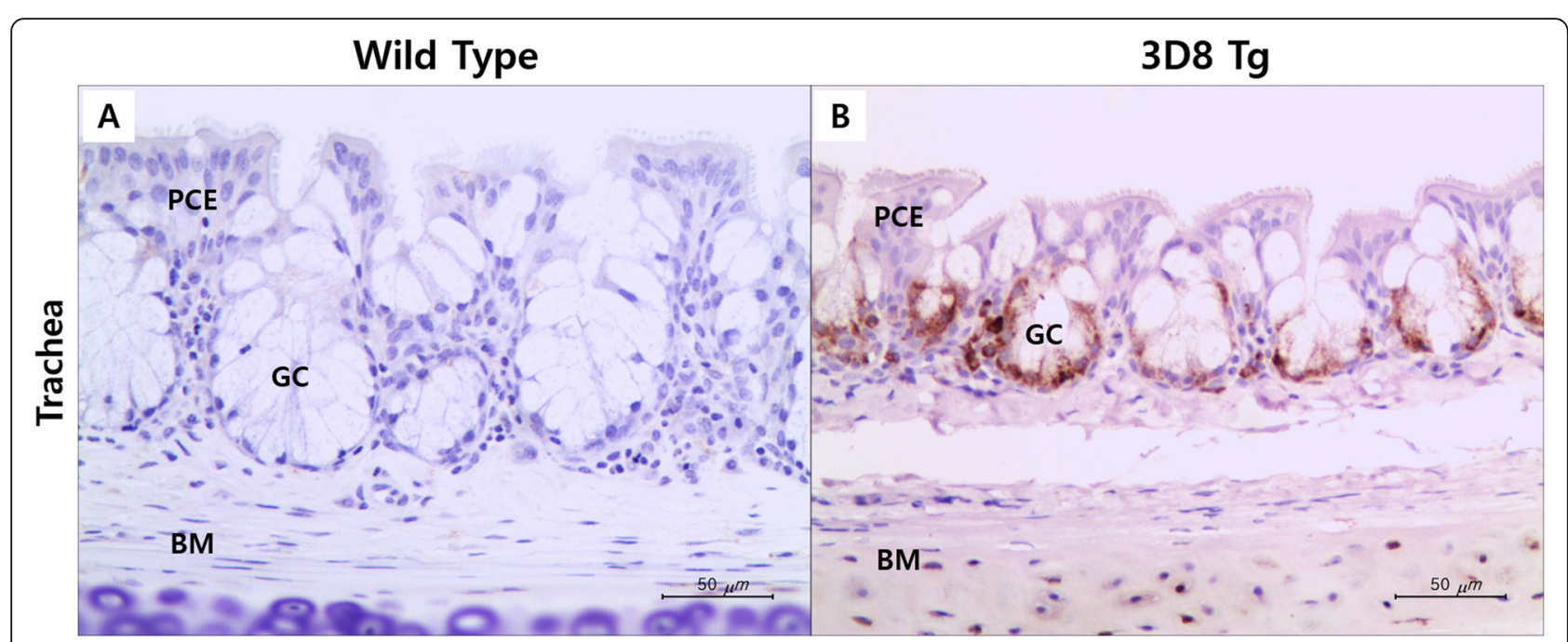

Fig. 2 Immunohistochemistry of the tracheal tissues against 3D8 scFv from wild-type (a) and 3D8 transgenic chickens (b). The tracheal tissue of the 3D8 scFv transgenic chicken exhibited a dark brown color after DAB staining. The 3D8 transgenic chicken showed stronger staining of the lymphocytes of the tracheal lamina propria surface. PCE, pseudostratified columnar ciliated epithelium; GC, goblet cells; BM, basement membrane. The scale bar represents $50 \mu \mathrm{m} .400 \mathrm{X}$

direct contact with afflicted birds or asymptomatic birds that carry the virus, and airborne transmission is also significant $[14,16]$. In particular, feathers that carry the virus can be transferred to other hosts through aerosols, suggesting that aerosol exposure is a crucial source of virus spread [17]. In addition, NDV infection may remain in a subclinical condition in immunized chickens $[18,19]$.

Commercial vaccination is the most significant process for the control and prevention of NDV. Inactivated and live ND vaccines are currently accessible worldwide [20]. However, it is important to understand the NDV maintenance mechanism. Experiments have shown that vaccines do not prevent replication by highly virulent viruses [6]. Many antiviral studies on NDV have taken conducted in response to these problems. Quantity of shedding, protection against mortality and clinical signs will depend on the immunity of the host. In this study, we demonstrated that expression of the 3D8 scFv in transgenic chickens could induce protection against aerosol exposure to NDV via direct antiviral effects of the 3D8 scFv, as was reported in our recent study $[13,15]$.

The 3D8 scFv is a mini-antibody that hydrolyzes nucleic acids without sequence specificity and is expected

Table 1 Mortality rate of the direct challenge group for 5 days after inoculation with NDV virus

\begin{tabular}{llll}
\hline Group & No. of Chickens & Mortality $^{a}$ & MDT $^{\mathrm{b}}$ \\
\hline Transgenic & 6 & $6 / 6$ & 4 \\
Non-transgenic & 6 & $6 / 6$ & 4 \\
SPF & 6 & $6 / 6$ & 3.8 \\
\hline
\end{tabular}

${ }^{\mathrm{a}}$ Mortality/Test number

${ }^{\mathrm{b}} \mathrm{MDT}$, mean death time to prevent viral replication [10]. The $3 \mathrm{D} 8 \mathrm{scFv}$ has antiviral activity against a broad range of viruses, including CSFV, pseudorabies virus (PRV), herpes simplex virus (HSV), murine norovirus (MNV) and H1N1 influenza virus [12, 13, 21]. Our results also confirmed that 3D8 scFv-expressing transgenic chickens could survive an indirect challenge via aerosol exposure to NDV. In our research, we generated a $3 \mathrm{D} 8 \mathrm{scFv} \mathrm{G}_{1}$ transgenic rooster with pLenti-CBA - 3D8 scFv-HA-IRES-puro vector that was mated with wild-type hens to produce $G_{2}$ transgenic chickens. Similarly, we produced $G_{2}$ transgenic chickens for experiments on antiviral activity against NDV by mating a $G_{1}$ transgenic rooster and wild-type hens. Genomic PCR analysis was performed to verify that the G2 transgenic chickens expressed the 3D8 scFv. In addition, we conducted immunohistochemical staining to confirm expression of the 3D8 scFv protein in $G_{2}$ transgenic chickens. The transgenic chickens showed high 3D8 $\mathrm{scFv}$ expression in lymphocytes on the tracheal lamina propria surface.

In previous study, expression of the 3D8 scFv in transgenic chickens showed that the 3D8 scFv is responsible for damaging the host genome and inducing apoptosis because the $3 \mathrm{D} 8 \mathrm{scFv}$ exhibits nuclease activity [15]. However, the lowest level of 3D8 scFv expression was tolerated by host cells and did not influence the expression of housekeeping RNAs, including $\beta$-actin mRNA [11]. In our previous study, we also stated that the transfected cells did not undergo apoptosis and that low levels of 3D8 scFv protein expression that did not induce apoptosis were expected in chickens. In this study, we developed $G_{2}$ transgenic chickens expressing the 3D8 $\mathrm{scFv}$ and no mortality was observed in the aerosol 


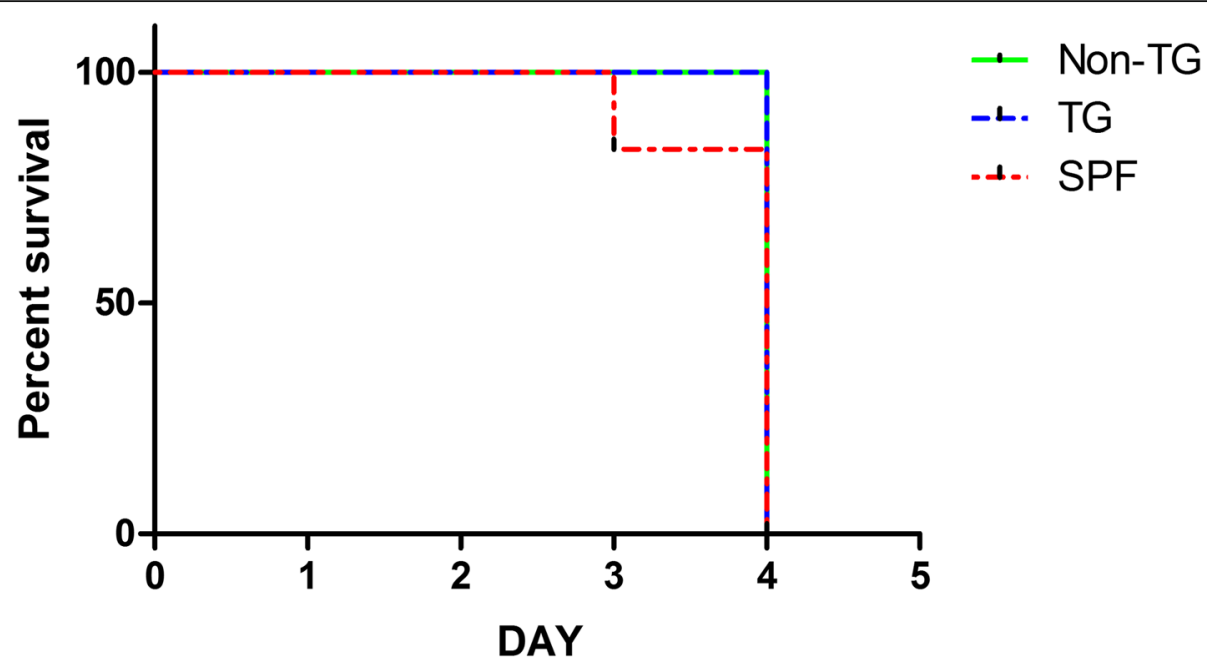

Fig. 3 The survival rates of chickens directly challenged with NDV. Six chickens per group were directly challenged by intramuscular injection with $1 \mathrm{ml}$ of $10^{5.5} \mathrm{EID}_{50} / \mathrm{ml}$ of velogenic NDV, Kr005 strain. Chickens were monitored daily for 5 days to measure the clinical signs and mortality rate

transmission group of 3D8 scFv transgenic chickens. However, no significant effects of 3D8 scFv expression were found in the direct infection groups $(\mathrm{p}<0.05)$. Since a low level of 3D8 scFv expression can exhibit antiviral activity and weakens viral infectivity in chickens, this result suggests that $3 \mathrm{D} 8 \mathrm{scFv}$ transgenic chickens could be useful to prevent the spread of NDV in chickens [15].

\section{Conclusions}

In conclusion, the result suggests that the $3 \mathrm{D} 8 \mathrm{scFv}$ protein potentially inhibits Newcastle disease virus spreading in chicken. Therefore, the $3 \mathrm{D} 8 \mathrm{scFv}$ is an effective antiviral protein that should be considered as a future alternative in the poultry industry. However, there are few reports on the antiviral effect of the 3D8 $\mathrm{scFv}$ protein in chickens, and thus, further scientific investigations are needed.

\section{Methods}

\section{Generating 3D8 scFv transgenic chickens}

In a prior study, we described a $3 \mathrm{D} 8 \mathrm{scFv} \mathrm{G}_{1}$ transgenic rooster which was generated with the pLenti-CBA - 3D8 scFv-HA-IRES-puro vector and mated this rooster with

Table 2 The mortality ratio of the indirect challenge group for 14 days after inoculation with NDV

\begin{tabular}{|c|c|c|c|}
\hline Group & No. of Chickens & Mortality ${ }^{a}$ & $\mathrm{MDT}^{\mathrm{b}}$ \\
\hline Transgenic & 10 & $0 / 10$ & - \\
\hline Non-transgenic & 10 & $10 / 10$ & 12 \\
\hline SPF & 10 & $10 / 10$ & 12.4 \\
\hline
\end{tabular}

${ }^{\mathrm{a}}$ Mortality/Test number

${ }^{\mathrm{b}} \mathrm{MDT}$, mean death time wild-type hens to produce $\mathrm{G}_{2}$ transgenic chickens [15]. PCR analysis (50 $\mu \mathrm{l}$ volume) was performed using the Phusion Blood Direct PCR Kit (Thermo Scientific). To detect the 3D8 scFv in the $G_{2}$ chickens, we performed PCR analysis using a forward primer (5'-CCTCTGCTAA CCATGTTCATGCCTTC-3') that anneals at the CBA promoter region and a reverse primer (5'-GCTAGTGA ATGTGTATCCAGAAGCCTT-3') that anneals at the 3D8 scFv region. The following conditions were used for this analysis: initial denaturation at $98^{\circ} \mathrm{C}$ for $5 \mathrm{~min} ; 40$ cycles of $98^{\circ} \mathrm{C}$ for $1 \mathrm{~s}, 62^{\circ} \mathrm{C}$ for $5 \mathrm{~s}$, and $72^{\circ} \mathrm{C}$ for $20 \mathrm{~s}$; and final extension at $72^{\circ} \mathrm{C}$ for $10 \mathrm{~min}$.

\section{Assessing 3D8 scFv protein expression in transgenic chickens by immunohistochemical staining}

Tracheal tissues were collected from transgenic and wild-type chickens and fixed in 10\% PFA. Tracheal tissue samples were frozen, and processed using a cryomicrotome (Leica CM3050S, Wetzlar, Germany). The resulting 3- $\mu \mathrm{m}$-thick segments of tracheal tissue were mounted on silane-coated slides. The tissue sections were incubated with HA-tagged (3D8) primary antibodies (1:1000 dilutions) for $12 \mathrm{hr}$ at $4{ }^{\circ} \mathrm{C}$. Biotinylated secondary antibodies were applied for $1 \mathrm{hr}$ at $4{ }^{\circ} \mathrm{C}$. Chromogen 3,3'-diaminobenzidine tetrahydrochloride (DAB) (10 min) with ABC Kit (Vector Laboratories, Burlingame, CA, USA) was used to detect expression, and hematoxylin was used for counterstaining (20 min). Finally, slides were observed under light microscopy (Leica DE/DMI6000B equipped with a Leica Microsystems CMS GmbH D-35578 Wetzlar digital camera (Leica, Germany)), and images were captured. Immunohistochemical analysis was performed according to Lee et al. (2019) [13, 22, 23]. 


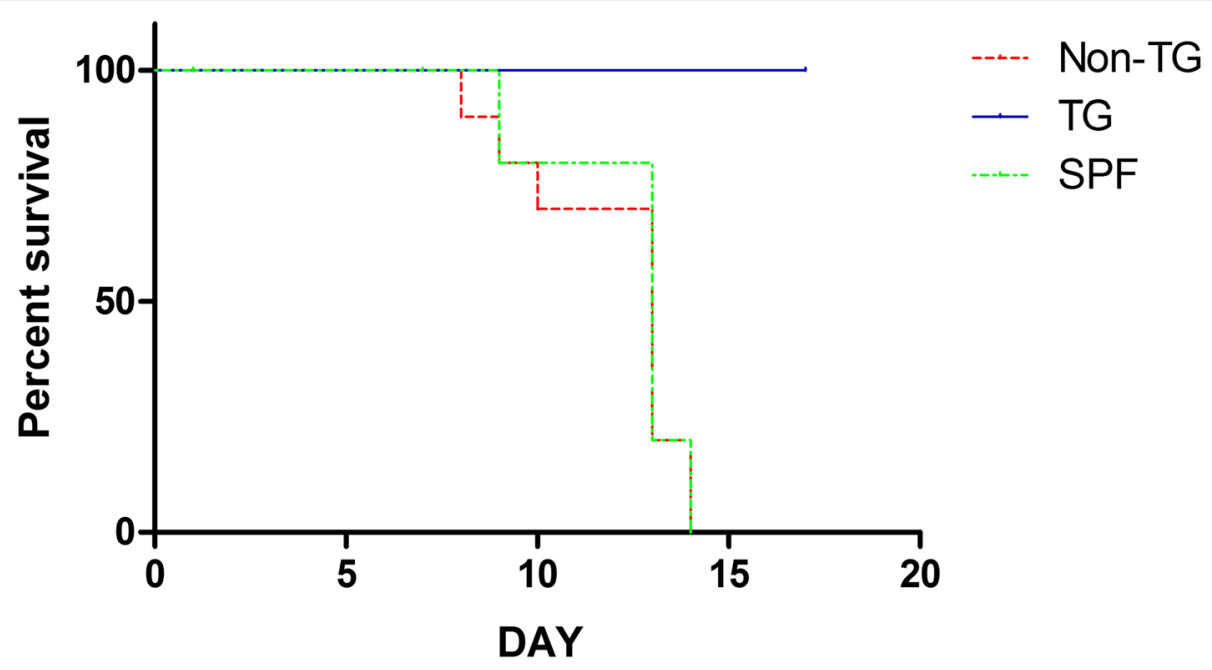

Fig. 4 The survival rate of chickens subjected to aerosol exposure to NDV. Ten chickens per group were housed in an aerosol exposure cage with unidirectional airflow from a direct challenge cage. The cages were connected with hoses $\left(70 \mathrm{~cm}\right.$ long, $10 \mathrm{~cm}$ diameter, $1.5 \mathrm{~m}^{2} / \mathrm{sec}$ airflows). Chickens were monitored daily for 14 days to measure the clinical signs and mortality rate

\section{In vivo NDV infection and transmission studies}

The challenge study with a live virus was conducted in a biosafety level 2 facility under the supervision of the Institutional Animal Care and Use Committee (IACUC) (KU 18185) of Konkuk University, South Korea. In total, forty-eight three-week-old transgenic, non-transgenic (non-TG), and specific pathogen-free (SPF) chickens were used $(n=16)$. SPF chickens were obtained from Namduck Sanitec, Korea. All chickens were confirmed to be serologically negative by $\mathrm{HI}$ test against NDV. HI assays were performed according to the OIE standard HI method using 4 hemagglutination units (HAU) of formalin-inactivated homologous antigen. Six chickens per group were randomly allocated and directly challenged by intramuscular injection with $1 \mathrm{ml}$ of $10^{5.5} 50 \%$ egg infective dose $\left(\mathrm{EID}_{50}\right) / \mathrm{ml}$ velogenic NDV, Kr005 strain. Six hours later, the remaining ten chickens per group were subjected to aerosol exposure to NDV through hoses $\left(70 \mathrm{~cm}\right.$ long, $10 \mathrm{~cm}$ in diameter, $1.5 \mathrm{~m}^{2}$ / sec airflow) with unidirectional airflow from the cages with directly challenged chickens by cage connection. During the experimental period, the chickens were observed daily to measure the mortality rate. All chickens were identified using individual tags; water and feed were supplied ad libitum. Chickens were euthanized by $\mathrm{CO} 2$ inhalation when they were reached a predetermined humane endpoint.

\section{Statistical analysis}

An analysis of variance (ANOVA) and Tukey-Kramer post-hoc test were used to compare the mortality between all groups. $P$-values $<0.05$ were considered to be significant.

\section{Supplementary information}

Supplementary information accompanies this paper at https://doi.org/10. 1186/s12917-020-02462-9.

Additional file 1: Figure S1. Confirmation of $3 D 8 \mathrm{scFv}$ gene expression in $G_{2}$ tg. Genomic PCRanalysis of the $G_{2} 3 D 8$ scFv tgprogeny chickens. The PCR product size is 270 bp. M: $1 \mathrm{~kb}$ Plus DNA ladder (SolGent), NC: negative control, PC: positive control.

\section{Abbreviations}

ND: Newcastle disease; scFv: Single chain variable fragment; PCR: Polymerase Chain Reaction; SPF: Specific pathogen-free

\section{Acknowledgements}

This study was performed as the 2015-2019 RDA Fellowship Program of the National Institute of Animal Science, Rural Development Administration, Republic of Korea.

\section{Authors' contributions}

CSS, SJB and JYN conceived and designed this study. SJB, SSY, HC, and SS wrote and edited manuscript. SSY, HCL and JHK assisted in the analysis for laboratory experiments and helped to collect serum samples were identified using genomic PCR. KBO, GL, SKJ, JSK and HY, conducted the experiments, and analyzed and checked the data. JSW and SS preparing figure. CSS and SJB supervised the experimental work and revised the manuscript. All authors read and approved the final manuscript.

\section{Funding}

This study was conducted with the funding support from the project "Cooperative Research Program for Agriculture Science \& Technology Development (Project No. PJ01094401)" of the Rural Development Administration, Republic of Korea for experiment and publication.

\section{Availability of data and materials}

The datasets used and analyzed during the current study are available from the corresponding author on reasonable request.

\section{Ethics approval and consent to participate}

The challenge study to animals with a live virus was conducted in a biosafety level 2 facility under the approval and supervision of the Institutional Animal Care and Use Committee (IACUC) (KU 18185) of Konkuk University, South Korea in accordance with the guidelines of the Konkuk University IACUC. 


\section{Consent for publication}

Not applicable.

\section{Competing interests}

The authors declare that there is no conflict of interest.

\section{Author details}

'Animal Biotechnology Division, National Institute of Animal Science, Rural Development Administration, 55365 Wanju-gun, Republic of Korea. ${ }^{2}$ Avian Disease Laboratory, College of Veterinary Medicine, Konkuk University, 1 Hwayang-dong, Gwangjin-gu, 05029 Seoul, Republic of Korea.

Received: 3 February 2020 Accepted: 6 July 2020

Published online: 06 August 2020

\section{References}

1. Iram N, Shah MS, Ismat F, Habib M, Iqbal M, Hasnain SS, Rahman M. Heterologous expression, characterization and evaluation of the matrix protein from Newcastle disease virus as a target for antiviral therapies. Appl Microbiol Biotechnol. 2014;98:1691-701.

2. Afonso CL, Miller PJ. Newcastle disease: progress and gaps in the development of vaccines and diagnostic tools. Dev Biol (Basel). 2013;135: 95-106.

3. Senne DA, King DJ, Kapczynski DR. Control of Newcastle disease by vaccination. Dev Biol (Basel). 2004:119:165-70.

4. Chambers P, Millar NS, Bingham RW, Emmerson PT. Molecular cloning of complementary DNA to Newcastle disease virus, and nucleotide sequence analysis of the junction between the genes encoding the haemagglutininneuraminidase and the large protein. J Gen Virol. 1986;67(Pt 3):475-86.

5. Cattoli G, Susta L, Terregino C, Brown C. Newcastle disease: a review of field recognition and current methods of laboratory detection. J Vet Diag Inve. 2011;23:637-56.

6. Kapczynski DR, King DJ. Protection of chickens against overt clinical disease and determination of viral shedding following vaccination with commercially available Newcastle disease virus vaccines upon challenge with highly virulent virus from the California 2002 exotic Newcastle disease outbreak. Vaccine. 2005;23:3424-33.

7. Shim JB, So HH, Won HK, Mo IP. Characterization of avian paramyxovirus type 1 from migratory wild birds in chickens. Avian Pathol. 2011;40:565-72.

8. Esaki M, Godoy A, Rosenberger JK, Rosenberger SC, Gardin Y, Yasuda A, Dorsey KM. Protection and antibody response caused by turkey herpesvirus vector Newcastle disease vaccine. Avian Dis. 2013;57:750-5.

9. Xiao S, Paldurai A, Nayak B, Mirande A, Collins PL, Samal SK. Complete genome sequence of a highly virulent newcastle disease virus currently circulating in Mexico. Genome Announc. 2013; 1.

10. Kim YR, Kim JS, Lee SH, Lee WR, Sohn JN, Chung YC, Shim HK, Lee SC, Kwon MH, Kim YS. Heavy and light chain variable single domains of an antiDNA binding antibody hydrolyze both double- and single-stranded DNAs without sequence specificity. J Biol Chem. 2006;281:15287-95.

11. Jang JY, Jeong JG, Jun HR, Lee SC, Kim JS, Kim YS, Kwon MH. A nucleic acid-hydrolyzing antibody penetrates into cells via caveolae-mediated endocytosis, localizes in the cytosol and exhibits cytotoxicity. Cell Mol Life Sci. 2009;66:1985-97.

12. Jun HR, Pham CD, Lim SI, Lee SC, Kim YS, Park S, Kwon MH. An RNAhydrolyzing recombinant antibody exhibits an antiviral activity against classical swine fever virus. Biochem Biophys Res Commun. 2010;395:484-9.

13. Lee G, Yu J, Cho S, Byun SJ, Kim DH, Lee TK, Kwon MH, Lee S. A nucleic-acid hydrolyzing single chain antibody confers resistance to DNA virus infection in hela cells and C57BL/6 mice. PLoS Pathog. 2014;10:e1004208.

14. Capua I, Alexander DJ. Avian influenza and Newcastle disease: a field and laboratory manual. Springer Science \& Business Media. 2009.

15. June BS, Yuk SS, Jang YJ, Choi H, Jeon MH, Erdene-Ochir TO, Kwon JH, Noh JY, Sun Kim J, Gyu Yoo J, Song CS. Transgenic Chickens Expressing the 3D8 Single Chain Variable Fragment Protein Suppress Avian Influenza Transmission. Sci Rep. 2017;7:5938.

16. Mayo MA. A summary of taxonomic changes recently approved by ICTV. Arch Virol. 2002;147:1655-63.

17. Hao H, Chen S, Wu P, Wang J, Duan X, Du E, Wang X, Yang Z. Genomic characterisation of two virulent Newcastle disease viruses isolated from crested ibis (Nipponia nippon) in China. Gene. 2014;553:84-9.
18. Alexander DJ. Avian Paramyxoviridae-recent developments. Vet Microbiol. 1990;23:103-14

19. Degefa T, Dadi L, Yami A, K GM, Nassir M. Technical and economic evaluation of different methods of Newcastle disease vaccine administration. J Vet Med A Physiol Pathol Clin Med. 2004;51:365-9.

20. van Boven M, Bouma A, Fabri TH, Katsma E, Hartog L, Koch G. Herd immunity to Newcastle disease virus in poultry by vaccination. Avian Pathol. 2008:37:1-5.

21. Lee G, Cho S, Hoang PM, Kim D, Lee Y, Kil EJ, Byun SJ, Lee TK, Kim DH, Kim S, Lee S. Therapeutic Strategy for the Prevention of Pseudorabies Virus Infection in C57BL/6 Mice by 3D8 scFv with Intrinsic Nuclease Activity. Mol Cells. 2015;38:773-80.

22. Devi L, Ohno M. PERK mediates elF2alpha phosphorylation responsible for BACE1 elevation, CREB dysfunction and neurodegeneration in a mouse model of Alzheimer's disease. Neurobiol Aging. 2014;35:2272-81.

23. Li X, Qiu Y, Yu A, Chai T, Zhang X, Liu J, Wang D, Wang H, Wang Z, Song C. Degenerate primers based RT-PCR for rapid detection and differentiation of airborne chicken Newcastle disease virus in chicken houses. J Virol Methods. 2009;158:1-5

\section{Publisher's Note}

Springer Nature remains neutral with regard to jurisdictional claims in published maps and institutional affiliations.
Ready to submit your research? Choose BMC and benefit from:

- fast, convenient online submission

- thorough peer review by experienced researchers in your field

- rapid publication on acceptance

- support for research data, including large and complex data types

- gold Open Access which fosters wider collaboration and increased citations

- maximum visibility for your research: over $100 \mathrm{M}$ website views per year

At BMC, research is always in progress.

Learn more biomedcentral.com/submissions 